\title{
PERTUMBUHAN IKAN MAS KOKI, Carrasius auratus PADA SISTEM AKUAPONIK DENGAN TANAMAN AIR YANG BERBEDA
}

\author{
Tutik Kadarini ${ }^{\#}$, Muhamad Yamin, Nurhidayat, dan Lili Sholichah \\ Balai Riset Budidaya Ikan Hias \\ Jl. Perikanan No. 13, Pancoran Mas, Depok
}

(Naskah diterima: 14 April 2021; Revisi final: 9 November 2021; Disetujui publikasi: 10 November 2021)

\begin{abstract}
ABSTRAK
Akuaponik adalah budidaya ikan dan tanaman hidroponik yang dipelihara bersama dalam satu sistem yang terintegrasi. Limbah budidaya ikan yang berasal dari sisa pakan dan metabolisme akan menghasilkan $\mathrm{NH}_{3}$ yang dalam dosis tertentu dapat meracuni ikan. Penggunaan tanaman dalam sistem akuaponik akan mereduksi konsentrasi $\mathrm{NH}_{3}$ sehingga meningkatkan kualitas air yang pada akhirnya akan mengoptimalkan pertumbuhan ikan. Penelitian ini bertujuan untuk mengetahui pertumbuhan ikan mas koki, Carrasius auratus, pertumbuhan tanaman yang dipelihara pada sistem akuaponik dengan jenis tanaman air berbeda. Sebanyak 20 ekor ikan mas koki, berukuran panjang total 2,79 $\pm 0,25 \mathrm{~cm}$ dan bobot 0,24 $\pm 0,083 \mathrm{~g}$ ditebar per wadah. Wadah yang digunakan berupa 12 pasang yang setiap pasangnya terdiri atas akuarium untuk tanaman air dan galon plastik volume $17 \mathrm{~L}$ untuk ikan mas koki yang dirangkai menggunakan sistem resirkulasi tertutup. Penelitian didesain dalam rancangan acak lengkap (RAL) yang terdiri atas empat perlakuan dan tiga ulangan. Perlakuan yang diberikan adalah tiga jenis tanaman air berbeda yaitu: (1) ikan mas koki + tanaman melati air (Echinodorus palifolius); (2) ikan mas koki + tanaman air anubias (Anubias barteri); (3) ikan mas koki + tanaman bacopa (Bacopa australis); dan (4) ikan mas koki tanpa ada tanaman air. Parameter yang diamati adalah pertumbuhan ikan dan tanaman air, sintasan ikan, dan kualitas air. Hasil penelitian menunjukkan bahwa panjang total dan bobot ikan mas koki $(7,50 \pm 0,05 \mathrm{~cm}$ dan $5,21 \pm 0,10 \mathrm{~g})$ yang dipelihara dalam sistem akuaponik dengan tanaman melati air lebih tinggi dan berbeda nyata $(P<0,05)$ dibanding kontrol $(7,19 \pm 0,16 \mathrm{~cm}$; dan 4,64 \pm 0,23 g). Kadar amonia pada perlakuan tanaman melati air $(0,411 \mathrm{mg} / \mathrm{L})$ lebih rendah dibanding kontrol (0,630 mg/L), karena akar tanaman menyerap amonia di air, tanaman hias air dapat digunakan dalam sistem akuaponik ikan air tawar.
\end{abstract}

KATA KUNCl: akuaponik; kualitas air; ikan mas koki; tanaman air; pertumbuhan ikan

ABSTRACT: Growth of gold fish, Carrasius auratus and different types of aquatic plants in aquaponic culture systems. By: Tutik Kadarini, Muhamad Yamin, Nurhidayat, and Lili Sholichah

Aquaponics is the cultivation of fish and hydroponic plants together in one integrated system. Fish farming wastes sourced from uneaten feed and faecal materials produce ammonia $\left(\mathrm{NH}_{3}\right)$ of which in certain doses can poison the fish. The use of plants in aquaponic systems will keep the concentration of $\mathrm{NH}_{3}$, at a balanced level ther eby increasing water quality which will optimize the fish growth. This study aimed to determine the growth of gold fish, Carrasius auratus reared in aquaponic systems using different types of aquatic plants. A total of 20 gold fish (total length of $2.79 \pm 0.25$ $\mathrm{cm}$ and weight of $0.24 \pm 0.083 \mathrm{~g}$ ) were reared per tanks. A pair of containers was used consisted of aquariums for aquatic plants and plastic gallons (volume $17 \mathrm{~L}$ ) for gold fish arranged in a closed recirculation system. The total number of containers used were 12 pairs. The experiment was arranged using a completely randomized design (CRD) consisting of four treatments and three replications. The treatments consisted of: (1) gold fish + Echinodorus palifolius; (2) gold fish + Anubias barteri; (3) gold fish + Bacopa australis; and (4) gold fish without aquatic plants (control). The parameters observed weregrowth of gold fish and aquatic plants, survival rate of gold fish, and water quality. The results showed that the total length and weight of gold fish $(7.50 \pm 0.05 \mathrm{~cm}$ and $5.21 \pm 0.10 \mathrm{~g})$ reared in an aquaponic system with water jasmine plants were higher and significantly different $(P<0.05)$ compared to control

\footnotetext{
\# Korespondensi: Balai Riset Budidaya Ikan Hias.

Jl. Perikanan No. 13, Pancoran Mas, Depok, Indonesia

E-mail: tutikdarso@gmail.com
} 
$(7.19 \pm 0.16 \mathrm{~cm}$, and $4.64 \pm 0.23 \mathrm{~g})$. Ammonia level in treatment of $\mathbf{E}$. palifolius $(0.411 \mathrm{mg} / \mathrm{L})$ was lower than control $(0.630 \mathrm{mg} / \mathrm{L})$ because plant roots absorb ammonia in water. Ornamental aquatic plants can be used in aquaponics systems for freshwater fish.

\section{KEYWORDS: aquaponic; water quality; goldfish; aquatic plants; fish growth}

\section{PENDAHULUAN}

Limbah budidaya seperti sisa pakan dan buangan metabolisme ikan menghasilkan $\mathrm{NH}_{3}$ dan $\mathrm{NO}_{2}$ yang dapat mengganggu dan menurunkan produksi ikan. Oleh karena itu, diperlukan sebuah cara yang dapat digunakan untuk mereduksi buangan metabolit tersebut. Salah satu upaya yang dapat dilakukan untuk menurunkan konsentrasi limbah dan meningkatkan produksi ikan adalah melalui sistem budidaya ikan akuaponik.

Teknologi akuaponik merupakan teknologi yang dapat meminimalisir limbah nitrogen dari sisa metabolisme ikan melalui integrasi sistem produksi tanaman sayur/kembang/herbal secara hidroponik ke dalam sistem akuakultur (Sumoharjo, 2010). Limbah yang dihasilkan oleh ikan berfungsi sebagai pupuk tanaman, di mana tanaman tersebut akan bertugas untuk menyerap kandungan nitrit, nitrat, dan amonia yang ada di air. Dengan demikian kualitas air akan lebih baik sebagai media ikan melalaui sistem resirkulasi. Pemilihan komoditas akuaponik yang tepat baik ikan maupun tanaman, maka sistem akuaponik ini dapat berfungsi sebagai model produksi ikan dan tanaman yang sesuai lingkungan dan berkelanjutan. Manfaat sistem akuaponik ini mencegah pembuangan limbah ke lingkungan, menyediakan pupuk organik, menggunakan air limbah (reuse) melalui proses biofiltrasi, serta dapat meningkatkan produktivitas. Akuaponik memiliki beberapa keuntungan antara lain mengoptimalkan budidaya tanaman dan ikan dengan mereduksi amonia $\left(\mathrm{NH}_{3}\right)$. Kandungan amonia yang rendah pada media pemeliharaan dapat meningkatkan pertumbuhan dan produktivitas ikan yang dipelihara.

Amonia dalam bentuk $\mathrm{NH}_{3}$ bersifat racun pada kegiatan budidaya yang dapat menyebabkan iritasi insang dan gangguan pernapasan (Molleda, 2007). Limbah budidaya atau nitrogen yang diserap oleh tanaman hampir seluruhnya dalam bentuk nitrat dan amonium. Jika tanaman menyerap hampir $100 \% \mathrm{~N}$ dalam bentuk amonium maka akan meningkatkan ketersediaan protein yang dapat digunakan untuk pertumbuhan tanaman tersebut (M angel \& Kirby, 1979).

Akuaponik dapat dilakukan di lahan yang sempit dengan teknik resirkulasi dapat mengurangi pemakaian air untuk budidaya ikan, mengurangi pencemaran limbah budidaya ikan, dan memastikan ketersediaan air bersih dan berkualitas untuk budidaya ikan. Beberapa hal yang perlu diperhatikan dalam akuaponik adalah luas lahan, jenis ikan, kepadatan ikan, jenis tanaman, media tanam, rancangan sistem akuaponik, parameter biotik, dan lingkungan. Pada umumnya selama ini akuaponik menggabungkan budidaya ikan dengan sayuran seperti kangkung dan slada. Riska et al. (2014) menyatakan dalam studi yang dilakukannya bahwa penelitian akuaponik budidaya ikan dengan jumlah sayuran kangkung yang berbeda, menunjukkan bahwa semakin banyak tanaman air makin efektif dalam mereduksi amonia, penggunaan 30 batang per rumpun kangkung dapat mengurangi amonia hingga $58,57 \mathrm{mg} / \mathrm{L}$. Studi lain yang dilakukan oleh Nugroho et al. (2012) mengenai sistem akuaponik pendederan ikan koi dengan varietas selada yang berbeda, menunjukkan yang terbaik adalah selada batavia yang dapat mereduksi kandungan amonia $\left(\mathrm{NH}_{3}\right)$ 0,21 mg/L menjadi 0,12 mg/L. Kemudian Firdaus (2018) menunjukkan bahwa media tanam yang terbaik dalam studi efektivitas media tanam selada dengan ikan nila sistem akuaponik adalah arang sekam dibanding dengan batu apung. Gumelar et al. (2017) memperlihatkan pada penelitian akuaponik ikan mas koki dengan tiga varietas selada yang berbeda yaitu Batavia, Romaine, dan Pakcoy, ditunjukkan bahwa konsentrasi nitrogen amonia total terkecil terdapat pada perlakuan tanaman selada varietas Batavia, yaitu sebesar 0,133 mg/L.

Jenis tanaman air dapat dikelompokan yaitu tanaman sayuran dan tanaman air. Jenis tanaman air di antaranya anubias, bacopa, dan melati. Jenis tanaman air dan ikan hias sudah dikenal oleh pembudidaya. Tanaman air ini digunakan sebagai pelengkap dalam aquascape antara tanaman air dan ikan hias. Selain berfungsi sebagai pemanis dalam akuarium, tanaman air juga berfungsi untuk memperbaiki kualitas air dalam akuarium. Penelitian akuaponik ikan hias dengan menggunakan tanaman hias belum banyak dilakukan ikan koki (Carassius auratus). Salah satu jenis ikan hias yang memiliki nilai ekonomi tinggi, ikan ini banyak digemari masyarakat karena memiliki bentuk badan yang menarik dan warna yang indah (Manurung et al., 2017). Saat ini budidaya ikan mas koki sudah banyak dilakukan masyarakat, salah satu kendalanya penurunan kualitas air yang cepat akibat dari kotoran ikan dan sisa pakan. Beberapa upaya untuk mempertahankan kualitas air di antaranya dengan filterisasi dan akuaponik (Fazil et al., 2017; Patil et al., 
2019). Dengan latar belakang tersebut maka perlu dilakukan penelitian ikan mas koki, Carrasius auratus dengan tanaman air yang berbeda dalam sistem akuaponik. Ikan mas koki ini sangat responsif dengan pakan pellet (buatan) sehingga sisa pakan dapat dimanfaatkan oleh tanaman dalam bentuk $\mathrm{NO}_{3}$. Tujuan penelitian ini untuk mengetahui pertumbuhan ikan mas koki dan jenis tanaman air yang berbeda dalam sistem akuaponik.

\section{BAHAN DAN METODE}

Penelitian dilakukan di Balai Riset Budidaya Ikan Hias (BRBIH) Depok selama 40 hari. Dalam sistem akuaponik biasanya digunakan dua komoditas yang dipelihara bersama dalam suatu sistem resirkulasi. Dalam kegiatan ini menggunakan wadah berupa akuarium dan galon plastik yang dirangkai menggunakan sistem resirkulasi tertutup. Wadah galon plastik sebanyak 12 buah diisi $17 \mathrm{~L}$ air untuk memelihara ikan yang ditempatkan lebih tinggi dan wadah akuarium sebanyak 12 buah berukuran $35 \mathrm{~cm} x$ $40 \mathrm{~cm} \times 35 \mathrm{~cm}$ untuk tanaman air. Air dari galon akan mengalir ke akuarium dengan sistem gravitasi, sedangkan air dari akuarium dialirkan ke atas dengan bantuan pompa air. Melalui gravitasi mengalir air kemudian dialirkan ke tangki ikan dengan siklus resirkulasi air secara kontinu.

Ikan mas koki, Carrasius auratus ditebar 20 ekor/ wadah berukuran panjang total 2,79 $\pm 0,25 \mathrm{~cm}$ dan bobot 0,24 $\pm 0,08 \mathrm{~g}$ sedangkan tanaman yang digunakan ada tiga jenis yaitu anubias (Anubias barteri), melati (Echinodorus palifolius), dan bacopa (Bacopa australis) yang masing-masing dimasukkan ke dalam pot yang diberi rockwool. Setiap akuarium diberi tanaman sebanyak delapan pot dan setiap pot ada satu rumpun tanaman.

Rancangan yang digunakan rancangan acak lengkap (RAL) yang terdiri atas empat perlakuan dan tiga ulangan. Jenis tanaman berbeda sekaligus sebagai perlakuan adalah (1) ikan mas koki (C. auratus) + melati (E. palifolius), (2) ikan mas koki (C. auratus) + anubias (A. barteri), (3) ikan mas koki (C. auratus) + bacopa (Bacopa australis), dan (4) ikan mas koki (C. auratus) tanpa ada tanaman air.

Ikan diberi pakan komersil (pelet) dengan kandungan protein $35 \%$ sebanyak $5 \%$ dari bobot badan dan frekuensi pemberian dua kali sehari yaitu pukul 8.00 dan 15,00 . Suhu ruangan $28,1^{\circ} \mathrm{C}-37,2^{\circ} \mathrm{C}$; kelembaban ruangan $44 \% 99 \%$ dan intensitas cahaya 148-557 lux.

Parameter yang diamati sintasan ikan yaitu rasio jumlah ikan akhir penelitian dengan jumlah ikan awal penelitian dikalikan $100 \%$ pertumbuhan mutlak ikan mas koki yaitu pertumbuhan akhir dikurangi pertumbuhan awal penelitian, yaitu panjang total, panjang standar, dan bobot (Effendi, 1997). Pertumbuhan tanaman air yaitu panjang akar, jumlah anak (tunas), dan jumlah daun (Nurmayanti, 2018) yang diukur pada awal dan akhir penelitian. Panjang akar diukur dari pangkal akar (leher akar) sampai ujung akar. Jumlah anak dan jumlah daun dihitung sebelum dan sesudah penelitian atau penambahan jumlah anak dan daun selama penelitian.

Kualitas air dianalisis di Laboratorium Kualitas Air BRBIH meliputi amonia, nitrat, nitrit, dianal isis dengan metode spektro (SNI) pH, oksigen, dan suhu dengan alat (SNI), kesadahan dengan metode kit tester. Untuk analisis unsur hara nitrogen $(\mathrm{N})$, fosfat $(\mathrm{P})$, dan kalium (K) dianalisis di Laboratorium Balai Penelitian Ternak Ciawi, Bogor dan bakteri di Laboratorium Kesehatan Organisme Akuatik IPB Bogor.

Parameter pertumbuhan (tanaman dan ikan mas koki), serta sintasan dianalisis software Minitab, bila ada perbedaan perlakuan $(P<0,05)$ selanjutnya uji lanjut BNT.

\section{HASIL DAN BAHASAN}

\section{Unsur Hara}

Unsur hara yang dianalisis pada media yang ada tanaman air adalah parameternya nitrogen, fosfat, dan kalium (NPK), Adapun hasil analisis NPK pada akhir penelitian semakin meningkat untuk semua perlakuan. Sumber NPK ini berasal dari sisa pakan dan sisa hasil metabolisme. Unsur hara NPK nilainya rendah pada perlakuan tanaman melati dibanding tanaman lain karena dimanfaatkan oleh tanaman (Tabel 1).

Hasil analisis unsur hara total nitrogen dalam air bentuknya nitrat, nitrit, dan amonia, pada perlakuan kontrol nilai nitrogen paling rendah dibanding perlakuan lainnya dalam hal ini dikarenakan unsur nitrogen tidak direduksi hanya berputar dalam sistem sirkulasi dari wadah tanpa tanaman/filter ke wadah pemeliharaan (budidaya) sehingga proses nitrifikasi kurang baik karena kandungan bakteri sedikit, sedangkan perlakuan yang ada tanamannya terjadi proses nitrifikasi lebih baik karena jumlah bakteri nitrifikasi lebih banyak atau bakteri dan oksigen akan mereduksi amonia. Tanaman melati unsur hara nitrogen lebih sedikit dibanding dengan perlakuan tanaman lain dikarenakan pada wadah filter melati proses nitrifikasi sangat baik dan unsur hara nitrogen dalam bentuk nitrat dan amonia juga banyak dimanfaatkan oleh tanaman melati paling banyak yang diserap melalui akar. 
Tabel 1. Kandungan mineral nitrogen, fosfat, dan kalium dalam media pemeliharaan akuaponik

Table 1. Concetrations of nitrogen, phosphate, and potassium in the aquaponics media

\begin{tabular}{lccc}
\hline \multirow{2}{*}{$\begin{array}{c}\text { Perlakuan } \\
\text { Treatments }\end{array}$} & \multicolumn{3}{c}{ Unsur hara/Nutrient (mg/L) } \\
\cline { 2 - 4 } & $\begin{array}{c}\text { Nitrogen } \\
\text { Nitrogen }\end{array}$ & $\begin{array}{c}\text { Fosfat } \\
\text { Phosphat }\end{array}$ & $\begin{array}{c}\text { Kalium } \\
\text { Potassium }\end{array}$ \\
\hline Melati air (E. palifolius) & $63-94$ & $0.01-0.12$ & $0.01-0.16$ \\
Anubias (A. barteri ) & $63-122$ & $0.01-0.17$ & $0.01-0.17$ \\
Bakopa (B. australis) & $63-131$ & $0.01-0.20$ & $0.01-0.26$ \\
Kontrol (Control) & $63-90$ & $0.01-0.30$ & $0.01-0.19$ \\
\hline
\end{tabular}

Menurut Zailani et al. (1993), nitrogen adalah unsur yang sangat penting bagi pertumbuhan tanaman karena merupakan bagian penting dari protoplasma, enzim, agen katalis biologis yang berfungsi mempercepat proses kehidupan. Dalam rangka untuk menyiapkan makanan untuk tanaman, tanaman juga memerlukan peranan nitrogen. Peranan nitrogen secara khusus pada tanaman adalah berperan dalam pertumbuhan vegetatif tanaman, memberikan warna pada tanaman, umur tanaman, penggunaan karbohidrat, dan lain-lain. Kebutuhan nitrogen lebih banyak dibanding unsur fosfat dan kalium. Menurut Darajat \& Fajar (2019), untuk mengetahui kebutuhan nitrogen dalam tanaman tebu dengan machine learning Support Vector Machine (SVM) sebagai klasifikasi sistem deteksi kebutuhan nitrogen padi berdasarkan warna daun.

Hal tersebut sesuai dengan pendapat Musa et al. (2007), yang menyatakan bahwa kerapatan atau ukuran populasi tanaman sangat penting untuk memperoleh hasil yang optimal, tetapi bisa terjadi persaingan dalam hara, air, dan ruang tumbuh, serta mengurangi perkembangan tinggi dan kedalaman akar tanaman. Unsur hara nitrogen dalam bentuk amonia dan nitrit dalam dosis tertentu akan berpengaruh terhadap pertumbuhan dan sintasan ikan.

\section{Pertumbuhan Ikan Mas Koki}

Pengamatan pertumbuhan ikan mas koki meliputi panjang total, panjang standar, dan bo bot ikan. Selama pemeliharaan 40 hari pertumbuhan ikan mas koki yang tertinggi dari perlakuan jenis melati dan yang terendah kontrol. Pertumbuhan panjang total 7,5 $\pm 0,15 \mathrm{~cm}$; panjang standar 4,97 $\pm 0,02 \mathrm{~cm}$; dan bobot 5,21 \pm $0,10 \mathrm{~g}$ yang terendah perlakuan kontrol adalah 7,19 $\pm 0,16 \mathrm{~cm}$; panjang standar 4,64 $\pm 0,23 \mathrm{~cm}$ dan bo bot $4,75 \pm 0,25 \mathrm{~g}$. Berdasarkan analisis statistik terlihat ada pengaruh perlakuan terhadap pertumbuhan ikan mas koki dengan sistem akuaponik $(P<0,05)$. Selanjutnya uji lanjut BNT bahwa perlakuan jenis melati berbeda dengan kontrol tetapi tidak berbeda dengan perlakuan jenis tanaman anubias dan bacopa (Tabel 2).

Pertumbuhan mutlak ikan mas koki pada akhir penelitian baik bobot, panjang total, dan panjang standar lebih baik pada semua perlakuan dibanding kontrol. Sedangkan pertumbuhan tertinggi pada perlakuan melati dalam hal ini dikarenakan bahwa melati pertumbuhan akarnya lebih panjang dibanding perlakuan lain sehingga mereduksi amonia pada saat proses nitrifikasi lebih baik akhirnya kualitas air lebih baik untuk mendukung pertumbuhan yang akhirnya pertumbuhan ikan mas koki bisa optimal. Sebaliknya yang perlakuan kontrol (tanpa adanya tanaman) pertumbuhanya paling rendah dibanding dengan perlakuan lain dikarenakan dengan tidak adanya tanaman proses nitrifikasi secara alami lebih lambat dibanding dengan perlakuan lainnya sehingga kualitas air kurang baik sehingga memengaruhi pertumbuhan atau pertumbuhan ikan tidak optimal. Hasil penelitian Ginting et al. (2014) menghasilkan pertumbuhan panjang total sekitar 5-5,8 cm dan bobot 3,5-5,3 g untuk mas koki yang dipelihara selama 40 hari dengan sistem resirkulasi dengan tebar 1-2 ekor/liter.

\section{Sintasan Ikan Mas Koki}

Sintasan ikan mas koki yang dihasilkan selama penelitian sekitar 95\%100\% terendah pada perlakuan kontrol $95 \pm 5$ dan yang tertinggi pada perlakuan tanaman bacopa $100 \pm 0$ berdasarkan analisis uji statistik bahwa tidak berpengaruh terhadap sintasan ikan mas koki dengan sistem akuaponik selama pemeliharaan 40 hari $(P>0,05)$ (Tabel 3).

Selama 40 hari ikan bisa menoleransi lingkungan untuk hidup akhirnya sintasannya tinggi akan tetapi perlakuan kontrol sudah cenderung menurun meskipun secara statistik tidak berbeda. Hasil penelitian Ginting et al. (2018) menghasilkan sintasan 94,4\%untuk ikan mas koki yang dipelihara selama 40 hari dengan sistem resirkulasi dengan tebar 1-2 ekor/liter. 
Tabel 2. Pertumbuhan dan sintasan ikan mas koki setelah 40 hari pemeliharan

Table 2. Growth and survival rate of gold fish after 40 days of rearing

\begin{tabular}{lccc}
\hline & \multicolumn{3}{c}{ Ikan mas koki (Gold fish) } \\
\cline { 2 - 4 } \multicolumn{1}{c}{ Perlakuan tanaman } \\
\cline { 2 - 4 } & $\begin{array}{c}\text { Bobot } \\
\text { Weight } \\
\text { (g) }\end{array}$ & $\begin{array}{c}\text { Panjang total } \\
\text { Total length } \\
\text { (cm) }\end{array}$ & $\begin{array}{c}\text { Panjang standar } \\
\text { Standard length } \\
\text { (cm) }\end{array}$ \\
\hline Melati air (E. palifolius) & $5.21 \pm 0.10^{\mathrm{a}}$ & $7.50 \pm 0.05^{\mathrm{a}}$ & $4.97 \pm 0.02^{\mathrm{a}}$ \\
Anubias (A . barteri ) & $4.79 \pm 0.32^{\mathrm{ab}}$ & $7.06 \pm 0.56^{\mathrm{ab}}$ & $4.75 \pm 0.42^{\mathrm{ab}}$ \\
Bakopa (B. australis) & $5.35 \pm 0 . .42^{\mathrm{ab}}$ & $7.44 \pm 0.16^{\mathrm{ab}}$ & $4.95 \pm 0.10^{\mathrm{ab}}$ \\
Kontrol (Control) & $4.75 \pm 0.25^{\mathrm{b}}$ & $7.19 \pm 0.16^{\mathrm{b}}$ & $4.64 \pm 0.23^{\mathrm{b}}$ \\
\hline
\end{tabular}

Keterangan: Huruf yang tidak sama dalam satu kolom menunjukkan berbed a nyata pada taraf $5 \%(P<0,05)$

Remarks: Different superscripts in the same column indicate significant difference at $5 \%$ confidence level $(P<0.05)$

Tabel 3. Sintasan ikan mas koki setelah 40 hari pemeliharan

Table 3. Survival of gold fish after 40 days of rearing

\begin{tabular}{ccccc}
\hline \multirow{2}{*}{$\begin{array}{c}\text { Ulangan } \\
\text { Replications }\end{array}$} & \multicolumn{4}{c}{ Perlakuan tanaman (Treatment plants) } \\
\cline { 2 - 5 } & $\begin{array}{c}\text { Melati air } \\
\text { E. palifolius }\end{array}$ & $\begin{array}{c}\text { Anubias } \\
\text { A. barteri }\end{array}$ & $\begin{array}{c}\text { Bakopa } \\
\text { B. australis }\end{array}$ & $\begin{array}{c}\text { Kontrol } \\
\text { Control }\end{array}$ \\
\hline 1 & 100 & 100 & 100 & 90 \\
2 & 100 & 95 & 100 & 95 \\
3 & 95 & 100 & 100 & 100 \\
\hline Rataan (Average) & $98.33 \pm 2.89^{\mathrm{a}}$ & $98.33 \pm 2.89^{\mathrm{a}}$ & $100 \pm 0.00^{\mathrm{a}}$ & $95 \pm 5.00^{\mathrm{a}}$ \\
\hline
\end{tabular}

Keterangan: Huruf yang sama dalam satu baris menunjukkan tidak berbeda nyata pada taraf $5 \%(P>0,05)$

Remarks: Different superscripts in the same row indicate significant difference at $5 \%$ confidence level $(P<0.05)$

Selain itu, dengan sistem resirkulasi di mana oksigen di media cukup baik membantu mereduksi amonia menjadi nitrat dan amonia yang berasal dari limbah pemeliharaan ikan masih dapat ditoleransi oleh ikan. Menurut Jangkaru et al. (1991), sistem akuaponik menghasilkan tingkat sintasan benih ikan mas ini cukup tinggi dan dianggap telah cukup memadai dan menyiratkan jenis tanaman hias, jumlah, dan jenis pakan yang diberikan, frekuensi pemberian pakan, serta kontrol terhadap parasit dan penyakit pada sistem akuaponik telah berjalan secara optimal. Selain itu, menurut Riska et al. (2014), sistem akuaponik menghasilkan sintasan ikan nila dan tidak berpengaruh dari hasil uji statistik. Pemeliharaan sistem akuaponik pendederan ikan nila kepadatan yang berberda 200600 ekor dengan tanaman kangkung.

\section{Pertumbuhan}

Pertumbuhan tiga jenis tanaman yang diamati meliputi jumlah helai daun, panjang akar, dan jumlah anak. Pertumbuhan tanaman yang terbaik adalah jenis tanaman melati dan yang terendah anubias. Hasil analisis statistik menunjukkan bahwa sistem akuaponik berpengaruh terhadap pertumbuhan jenis tanaman $(P<0,05)$. Selanjutnya uji BNT bahwa perlakuan jenis tanaman melati berbeda dengan anubias tetapi tidak berbeda dengan bacopa sedangkan perlakuan jenis tanaman anubias dan bacopa tidak berbeda disajikan Tabel 4.

Pada Tabel 4, jumlah anak dari ketiga jenis tanaman adalah hanya tanaman melati yang mempunyai anak 34 atau rata-rata 3,22 $\pm 0,94$ sedang tanaman lain belum tumbuh anak. Pertumbuhan anak selain dipengaruhi oleh unsur hara juga genetik, karena ada jenis tanaman yang tumbuhnya lambat (Gambar 1).

Fahn (1995) menunjukkan bahwa fungsi utama adalah menjalankan sintesis senyawa-senyawa organik dengan menggunakan cahaya sebagai sumber energi yang diperlukan, yang dikenal dengan nama fotosintesis. Proses perubahan energi berlangsung dalam organel sel khusus yang disebut kloroplas. Fotosintesis membutuhkan air yang mengandung nutrisi dan $\mathrm{CO}_{2}$ yang dibantu dengan cahaya matahari yang cukup. Amonia dalam bentuk $\mathrm{NH}_{4}+$ (amonium) sebagian langsung dimanfaatkan oleh tanaman dan 


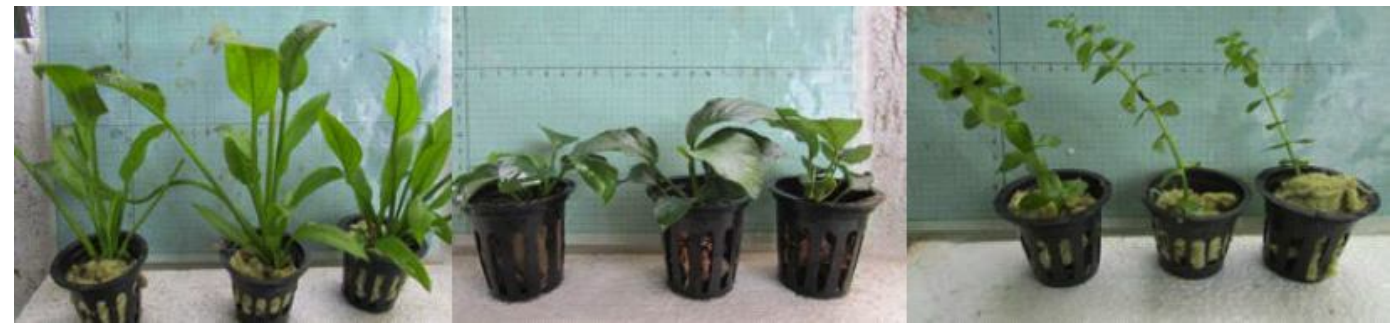

Gambar 1. Perbandingan antara tanaman dan anakan; 1) melati E. palifolius, 2) anubias A. barteri, 3) bacopa B. australis.

Figure 1. Comparison of the plants used and their child; 1) Echinodorus palifolius, 2) Anubias barteri, 3) Bacopa australis.

sebagian lagi diuraikan ke dalam bentuk nitrat terlebih dahulu dengan bantuan bakteri nitrifikasi sebelum dimanfaatkan oleh tanaman. Menurut Mangel \& Kirkby (1979), nitrogen diserap oleh tanaman hampir seluruhnya dalam bentuk amonium dan nitrat.

Jumlah helai daun tanaman yang paling tinggi hingga terendah yaitu tanaman melati $42,00 \pm 0,693 \%$ bacopa $23,62 \pm 23,53 \%$ dan anubias 3,67 $\pm 3,51 \%$ Hasil perhitungan analisis ragam menunjukkan bahwa perbedaan jenis tanaman berpengaruh secara nyata terhadap pertumbuhan tanaman, yaitu persentase helai daun tanaman $(P<0,05)$. Hasil pengamatan tersebut menunjukkan bahwa pada sistem akuaponik, faktor jenis tanaman berpengaruh terhadap pertumbuhan jumlah helai daun tanaman air. Panjang akar dan jumlah helai daun merupakan parameter pertumbuhan tanaman air (Adiwidjaja \& Rahmat, 1997). Dalam sistem akuaponik, efektivitas sistem juga diindikasikan dengan keberhasilan pertumbuhan tanaman air. Sistem ini memungkinkan tanaman tumbuh dengan memanfaatkan unsur-unsur limbah budidaya ikan yaitu amonia yang berasal dari sisa pakan yang tidak tercerna dan sisa metabolisme ikan (feces).

Pertumbuhan panjang akar dengan persentase sekitar $23,5 \% 450,45 \%$ yang paling panjang hingga yang terendah. Terpanjang pada tanaman melati 450,43 $\pm 50,13 \%$ bacopa $89,71 \pm 63,24$; dan yang terendah anubias 30,11 $\pm 9,91 \%($ Gambar 2$)$.

Hubungannya pertumbuhan akar dengan helai daun, anak, dan panjang akar yaitu semakin panjang akar atau cepat maka helai daun dan anak semakin banyak. Karena dengan semakin panjang akar maka jangkauan untuk menyerap nutrien lebih banyak sehingga pertumbuhan daun dan anak lebih banyak atau optimal bila dibanding panjang akar lebih pendek seperti tanaman anubias.

\section{Kualitas Air}

Kualitas air untuk parameter amonia dapat dipengaruhi oleh bakteri nitrifikasi karena akan mereduksi amonia yang merupakan racun bagi ikan. Bakteri yang dihasilkan jumlahnya berbeda untuk setiap perlakuan dapat dilihat pada Tabel 5. Jumlah bakteri yang tertinggi pada perlakuan tanaman melati air dan jumlahnya tidak terhitung, tingginya bakteri dikarenakan salah satunya dari akar, pertumbuhan akar melati yang terpanjang dibandingkan dari tanaman bacopa dan anubias, sedangkan akar digunakan sebagai substrat bagi bakteri sehingga tanaman melati jumlah bakteri terbanyak.

Tabel 4. Persentase pertumbuhan tanaman air melati, anubias, dan bacopa setelah 40 hari

Table 4. Growth percentage of the aquatic plants (E. palifolius, Anubias barteri, and Bacopa australis) after 40 days of the experiment

\begin{tabular}{lccc}
\hline $\begin{array}{c}\text { Jenis tanaman } \\
\text { Plant type }\end{array}$ & $\begin{array}{c}\text { Jumlah tunas } \\
\text { Number of shoots }\end{array}$ & $\begin{array}{c}\text { Jumlah daun } \\
\text { Number of leaves (\%) }\end{array}$ & $\begin{array}{c}\text { Panjang akar } \\
\text { Root length }(\%)\end{array}$ \\
\hline Melati air (E. palifolius) & $0.49 \pm 0.13$ & $1.62 \pm 0.01^{\mathrm{a}^{* *}}$ & $2.65 \pm 0.05^{2^{* *}}$ \\
Anubias (A. barteri) & 0 & $0.70 \pm 0.16^{\mathrm{b}^{* *}}$ & $1.45 \pm 0.15^{\mathrm{b}^{* *}}$ \\
Bakopa (B. australis) & 0 & $1.52 \pm 0.15^{\mathrm{a}^{* *}}$ & $1.80 \pm 0.38^{\mathrm{bc*}}$ \\
\hline
\end{tabular}

Keterangan: Sebelum diuji statistik data ditranformasi dulu, huruf yang tidak sama dalam satu kolom menunjukkan berbeda nyata pada taraf $5 \%(P<0,05)$

Remarks: Different superscripts in the same column indicate significant difference at $5 \%$ confidence level $(P<0.05)$ 

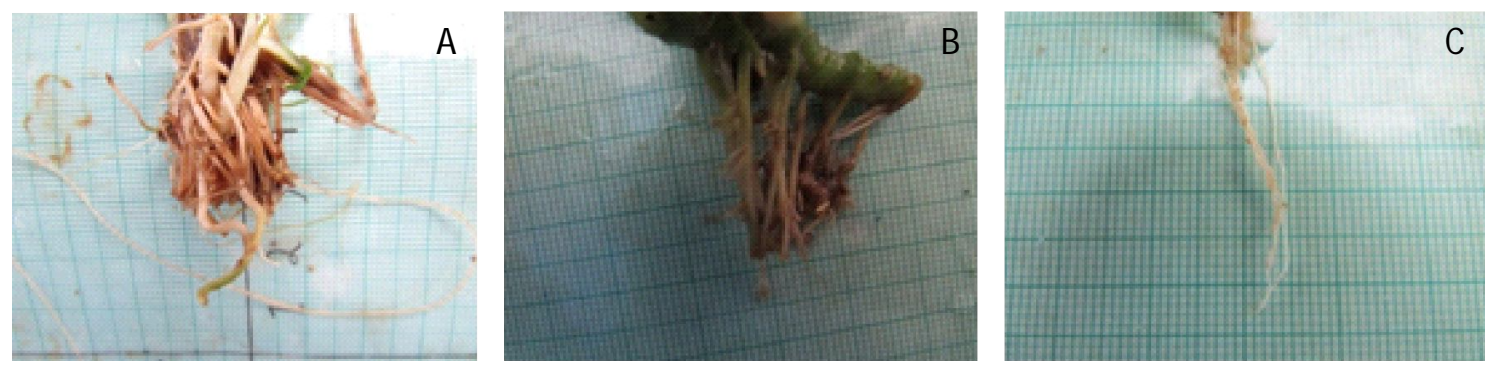

Gambar 2. Akar tanaman: 1) melati E. palifolius; 2) anubias A. barteri; 3) bacopa B. australis. Figure 2. Plant roots: 1) Echinodorus palifolius; 2) Anubias barteri; 3) Bacopa australis.

Tabel 5. Total bakteri di setiap perlakuan dari air di media tanaman

Table 5. Total bacteria counts in the rearing media of each treatment

\begin{tabular}{lc}
\hline \multicolumn{1}{c}{ Perlakuan (Treatments) } & Jumlah bakteri (Number of bacteria) \\
\hline Melati air (E. palifolius) & TBUD (Tidak terhitung karena padat) \\
Anubias (A. barteri ) & $3.9 \times 10^{1}$ \\
Bakopa (B. australis) & $1.7 \times 10^{2}$ \\
Kontrol (Control) & $0.5 \times 10^{1}$ \\
\hline
\end{tabular}

Pada kegiatan budidaya dengan sistem tanpa pergantian air, bakteria memiliki peranan penting dalam menghilangkan partikel amonia melalui proses nitrifikasi (Rully, 2011).

Hasil analisis kualitas air dari media tanam di akuarium selama penelitian untuk parameter suhu, $\mathrm{pH}$, dan DO nilainya hampir sama untuk semua perlakuan dan masih bisa ditolelir oleh ikan (Effendi, 2003) (Tabel 6).

Parameter kesadahan air, perlakuan yang ada tanaman lebih rendah dibanding kontrol. Rendahnya kesadahan karena dimanfaatkan oleh tanaman dan penyusun kesadahan seperti mineral-mineral tertentu di dalam air, umumnya ion kalsium (Ca) dan magne- sium $(\mathrm{Mg})$ dalam bentuk garam karbonat. Selain ion kalsium dan magnesium, penyususn kesadahan juga bisa merupakan ion logam lain maupun garam-garam bikarbonat dan sulfat (Effendi, 2003). Penyebab air menjadi sadah adalah karena adanya ion-ion $\mathrm{Ca}^{2+}$, $\mathrm{Mg}^{2+}$, atau dapat juga disebabkan karena adanya ionion lain dari polyvalent metal (logam bervalensi banyak) seperti $\mathrm{Al}, \mathrm{Fe}, \mathrm{Mn}, \mathrm{Sr}$, dan $\mathrm{Zn}$ dalam bentuk garam sulfat, klorida, dan bikarbonat dalam jumlah kecil (0fish, 2003).

Parameter amonia nilai cukup tinggi sekitar 0,409$0,415 \mathrm{mg} / \mathrm{L}$; sedangkan kontrol 0,630 mg/L. Menurut Gumelar et al. (2017), bahwa teknik akuaponik tanaman selada air dan ikan mas koi menghasilkan

Tabel 6. Kisaran parameter kualitas air selama penelitian

Table 6. Ranges of water quality parameters observed during the experiment

\begin{tabular}{lcccc}
\hline \multirow{2}{*}{$\begin{array}{c}\text { Parameter } \\
\text { Parameters }\end{array}$} & \multicolumn{3}{c}{ Perlakuan (Treatments) } & Kontrol \\
\cline { 2 - 4 } & $\begin{array}{c}\text { Melati } \\
\text { E. palifolius }\end{array}$ & $\begin{array}{c}\text { Anubias } \\
\text { A. barteri }\end{array}$ & $\begin{array}{c}\text { Bakopa } \\
\text { B. australis }\end{array}$ & \\
\hline Control \\
SHhu air (Temperature) $\left({ }^{\circ} \mathrm{C}\right)$ & $26.6-27.9$ & $25.9-27.6$ & $25.9-27.6$ & $25.9-28.4$ \\
Oksigen terlarut & $5-7$ & $5-7$ & $5-7$ & $5-7$ \\
Dissolved oxygen $(\mathrm{mg} / \mathrm{L})$ & $4.86-6.27$ & $4.86-6.27$ & $4.71-5.78$ & $4.86-6.7$ \\
Kesadahan (Hardness) $(\mathrm{mg} / \mathrm{L})$ & $33.71-122.18$ & $33.71-124.09$ & $33.71-127.8$ & $33.71-188.19$ \\
Amonia (Ammonia) $(\mathrm{mg} / \mathrm{L})$ & $0.031-0.411$ & $0.031-0.409$ & $0.031-0.415$ & $0.031-0.630$ \\
Nitrit (Nitrite) $(\mathrm{mg} / \mathrm{L})$ & $0.028-0.127$ & $0.028-0.112$ & $0.028-0.118$ & $0.028-0.127$ \\
Nitrat (Nitrate) $(\mathrm{mg} / \mathrm{L})$ & $0.077-0.175$ & $0.077-0.181$ & $0.077-0.189$ & $0.77-0.153$ \\
\hline
\end{tabular}


total amonia air setiap perlakuan varietas tanaman total amonia selada Batavia 0,399 $\mathrm{mg} / \mathrm{L}$; selada Romaine $0,463 \mathrm{mg} / \mathrm{L}$; dan pakcoy 0,697 mg/L; sedangkan tanpa tanaman atau kontrol 1,417 mg/L.

Setelah sekitar 10 hari pemeliharaan warna air berangsur berubah menjadi kuning kehijauan yang mengindikasikan terjadinya nitrifikasi baik dari tiga perlakuan yang menggunakan tiga jenis tanaman melati, anubias, dan bacopa. Amonia dalam bentuk $\mathrm{NH}_{3}$ atau amonium $\left(\mathrm{NH}_{4}+\right.$ ) merupakan senyawa yang mengandung unsur nitrogen $\left(\mathrm{N}_{2}\right)$ yang dimanfaatkan oleh tanaman.

Sistem akuaponik mereduksi amonia dengan menyerap air buangan budidaya atau air limbah dengan menggunakan akar tanaman sehingga amonia yang terserap mengalami proses oksidasi dengan bantuan oksigen dan bakteri, amonia diubah menjadi nitrat (Widyastuti, 2008).

Nitrat dalam perairan tidak merupakan racun bagi ikan dan nilai nitrat pada perlakuan kontrol kisaran lebih rendah dibanding yang ada tanaman dalam hal ini dikarenakan dengan adanya tanaman atau sistem akuaponik maka akar tanaman sebagai subtract bakteri yang membantu nitrifikasi sehingga amonia dalam proses oksidasi dengan bantuan oksigen dan bakteri, amonia diubah menjadi nitrat (Widyastuti, 2008). Pada kegiatan budidaya dengan sistem tanpa pergantian air, bakteria memiliki peranan penting dalam menghilangkan partikel amonia melalui proses nitrifikasi (Rully, 2011).

Hasil pengamatan menunjukkan bahwa kandung amonia $\left(\mathrm{NH}_{3}\right)$ dalam media yang ada tanaman lebih rendah dibandingkan media yang tanpa ada tanaman atau kontrol. Hasil pengamatan menunjukkan bahwa kandungan $\mathrm{pH}$ air dalam media hampir sama untuk semua perlakuan dengan meningkatnya nilai $\mathrm{pH}$ dan suhu perairan, apabila konsentrasinya tinggi dapat memengaruhi kehidupan ikan.

Sistem akuaponik tidak dapat dilepaskan dengan proses daur nitrogen dan nitrifikasi dalam media perairan budidaya. Nitrogen di dalam perairan dapat berupa nitrogen organik dan nitrogen anorganik. Nitrogen anorganik dapat berupa amonia $\left(\mathrm{NH}_{3}\right)$, amonium $\left(\mathrm{NH}_{4}+\right)$, nitrit $\left(\mathrm{NO}_{2}\right)$, nitrat $\left(\mathrm{NO}_{3}\right)$, dan molekul nitrogen $\left(\mathrm{N}_{2}\right)$ dalam bentuk gas. Sedangkan nitrogen organik adalah nitrogen yang berasal bahan berupa protein, asam amino, dan urea. Bahan organik yang berasal dari sisa pakan dan feces ikan akan mengalami pembusukan mineral yang terlepas dan utama adalah garam-garam nitrogen (berasal dari asam amino penyusun protein). Proses pembusukan tadi mula-mula terbentuk amonia $\left(\mathrm{NH}_{3}\right)$ sebagai hasil perombakan asam amino oleh berbagai jenis bakteri aerob dan anaerob. Pembongkaran itu akan menghasilkan suatu gas $\mathrm{CO}_{2}$ bebas, menurut persamaan reaksinya adalah:

$$
\text { R.CH. } \mathrm{NH}_{2} \cdot \mathrm{COOH}+\mathrm{O}_{2} \rightarrow \mathrm{R} \cdot \mathrm{COOH}+\mathrm{NH}_{2}+\mathrm{CO}_{2}
$$

Bila keadaan perairan semakin buruk, sehingga $\mathrm{O}_{2}$ dalam air sampai habis, maka secara perlahan proses pembongkaran bahan organik akan diambil oleh bakteri lain yang terkenal ialah Nitrosomonas menjadi senyawa nitrit. Reaksi tersebut sebagai berikut:

$$
\begin{aligned}
& \mathrm{NH}_{2}+\mathrm{HCO}_{2^{-}}+\text {phosphorous }+ \\
& \text { trace element } \rightarrow \text { bacterial biomass }+\mathrm{NO}_{2^{-}}+\mathrm{H}
\end{aligned}
$$

Bila perairan tersebut cukup mengandung kationkation maka asam nitrit yang terbentuk itu dengan segera dapat dirubah menjadi garam-garam nitrit, oleh bakteri Nitrobacter, garam-garam nitrit itu selanjutnya dikerjakan lebih lanjut menjadi garam-garam nitrat, reaksinya sebagai berikut:

$$
\begin{aligned}
& \mathrm{NO}_{2-}+\mathrm{HCO}_{2-}+\text { phosphorous }+ \\
& \text { trace element } \rightarrow \text { bacterial biomass }+\mathrm{NO}_{2}
\end{aligned}
$$

Garam-garam nitrit itu penting sebagai mineral yang diasimilasikan oleh tumbuh-tumbuhan hijau untuk menyusun asam amino kembali dalam tubuhnya, untuk menbentuk protoplasma itu selanjutnya tergantung pada nitrit, fitoplankton itu selanjutnya menjadi bahan makanan bagi organisme yang lebih tinggi. Nitrit tersebut pada suatu saat dapat dibongkar lebih lanjut oleh bakteri denitrifikasi (Micrococcus denitrifikan), bacterium nitroxus menjadi nitrogen-nitrogen bebas, reaksinya sebagai berikut:

$$
\begin{aligned}
& 5 \mathrm{C}_{6} \mathrm{H}_{12} \mathrm{O}_{6}+24 \mathrm{HNO}_{3} \rightarrow 24 \mathrm{H}_{2} \mathrm{CO}_{3}+6 \mathrm{CO}_{3}+ \\
& 18 \mathrm{H}_{2} \mathrm{O}+12 \mathrm{~N}_{2}
\end{aligned}
$$

Bila kadar $\mathrm{NH}_{3}$ hasil pembongkaran bahan organik di dalam air terdapat dalam jumlah besar, yang disebabkan proses pembongkaran protein terhenti sehingga tidak terbentuk nitrat sebagai hasil akhir, maka air ini disebut sedang mengalami pengotoran (pollution) (Metcalf \& Eddy, 1991). Pengotoran atau polusi pada media air budidaya inilah yang kemudian melalui sistem sirkulasi akan dicuci ke dalam tanaman dan termanfaatkan oleh akar-akar sebagai pupuk alami bagi pertumbuhan tanaman air. Air hasil tangkapan tersebut akan menjadi bersih dan dapat dimanfaatkan kembali sebagai media akuakultur melalui proses akuaponik. Amonia $\left(\mathrm{NH}_{3}\right)$ merupakan polutan langsung dari kegiatan budidaya ikan. Keberadaan sistem akuaponik, sesuai hasil penelitian ternyata mampu memberikan perbaikan kualitas air melalui reduksi kandungan amonia. Parameter-parameter kualitas air lain seperti pH, DO, dan nitrit menunjukkan hasil yang 
tidak berpengaruh secara nyata. Hal ini diduga karena kondisi media perairan budidaya masih dalam kondisi yang ideal pada sistem pendederan normal, sehingga pada sistem akuaponik tidak menunjukkan perbedaan perbaikan kondisi media secara nyata. Kandungan NPK dalam air berasal terutama sisa pakan buatan, kandungan $\mathrm{P}$ dan $\mathrm{K}$ pada perlakuan tanaman melati nilai kecil dibanding perlakuan lain dalam hal ini mineral tersebut dimanfaatkan oleh tanaman melati untuk pertumbuhan.

Effendi (2003) kadar amonia bebas yang tidak terionisasi sebaiknya tidak lebih dari $0,2 \mathrm{mg} / \mathrm{L}$. Konsentrasi amonia 0,4-3,1 mg/L dapat menyebabkan kematian sebesar $50 \%$ dari populasi ikan dalam waktu 96 jam (Boyd, 1982 dalam Ratannanda, 2011).

\section{KESIMPULAN}

Ikan mas koki, C. auratus yang dipelihara dalam sistem akuaponik dengan tanaman melati air lebih baik dan berbeda nyata dibanding kontrol $(P<0,05)$. Melati air memiliki pertumbuhan akar yang paling panjang dibanding tanaman lain atau kontrol. Sehingga lebih efektif dalam menurunkan amonia baik sebagai tempat berkembangnya bakteri atau dalam proses nitrifikasi. Tanaman melati air dapat digunakan dalam sistem akuaponik untuk ikan air tawar.

\section{UCAPAN TERIMA KASIH}

Diucapkan terima kasih kepada Bayu atas bantuannya dalam menganalisis kualitas air dan Sanusi atas bantuannya dalam merawat dan sampling ikan selama kegiatan penelitian di lapangan.

\section{DAFTAR ACUAN}

Adiwidjaja \& Rahmat. (1997). Pengaruh jenis dan dosis pupuk kandang terhadap pertumbuhan dan hasil tanaman kangkung darat (Ipomoeae reptans) kultivarsutera pada inceptisol. Laporan penelitian Lembaga Penelitian Universitas Padjadjaran Fakultas Pertanian UNPAD.

Agung, N.R., Pambudi, L.T., Chilmawati, D., \& Haditomo, A.H.C. (2012). Aplikasi teknologi aquaponik pada budidaya ikan air tawar untuk optimalisasi kapasitas produksi. Jurnal Saintek Perikanan, 8(1), 46-51.

Darajat \& Fajar, G. (2019). Deteksi kebutuhan nitrogen untuk penentuan jumlah pupuk pada tanaman padi berdasarkan warna daun menggunakan support vector machine. Tesis. Universitas Komputer Indonesia Bandung, $101 \mathrm{hlm}$.
Dauhan, R.E.S., Efendi, E., \& Suparmono. (2014). Efektifitas sistem akuaponik dalam mereduksi konsentrasi amonia pada sistem budidaya ikan. Jurnal Litkayasa dan Teknologi Budidaya (JRTBP), 3(1), 297-301.

Effendi, H. (2003). Telaah kualitas air bagi pengelolaan sumber daya dan lingkungan perairan. Yogyakarta: Kanisius, $258 \mathrm{hlm}$.

Effendi, M.I. (1997). Biologi perikanan. Bogor: Yayasan Pustaka Dewi Sri, 112 hlm.

Fazil, M., Adhar, S., \& Ezraneti, R. (2017). Efektivitas penggunaan ijuk, jerami padi dan ampas tebu sebagai filter air pada pemeliharaan ikan mas koki (Carassius Auratus). Acta Aquatica, 4, 1(April) 3743.

Fahn, A. (1990). Anatomi tumbuhan. Terjemahan Sitti Soetarmi Tjitrosoemo dan Tim. Yogyakarta: UGM Press.

Ginting, A., Syammaun, U., \& M aragunung, D. (2014). Pengaruh padat tebar terhadap kelangsungan hidup dan laju pertumbuhan ikan mas koki (Carassius auratus) yang dipelihara dengan sistem resirkulasi. Jurnal Aquacoastmarine. Program Studi Manajemen Sumberdaya Perairan, Fakultas Pertanian, Univeritas Sumatera Utara. $10 \mathrm{hlm}$.

Jangkaru, Z., Widiyati, A., Hardjamulia, A., Sukadi, F., Suhenda, N., Yuliati, P., Surisno, Taufik, P., \& Haryani, Y.P. (1991). Petunjuk teknis budidaya ikan nila. Puslitbang Perikanan, Badan Litbang Pertanian.

Mangel \& Kirkby, E.A. (1979). Principle of plant nutrition (2). International Potash Institute, Berne, Switzerland.

Manurung, S., Basuki, F., \& Desrina. (2017). Pengaruh lama perendaman hormon tiroksin terhadap daya tetas telur, pertumbuhan, dan kelangsungan hidup larva ikan mas koki (Carassius auratus). Journal of Aquaculture Management and Technology, 6(4), 202211.

Metcalf \& Eddy. (1991). Wastewater engineering treatment disposal reuse. Singapore: M cGraw-Hill Book Co.

Molleda, M.I. (2007). Water quality in recirculating aquaculture systems for arctic charr (Salvelinus alpinus L.) culture. United Nation University, Iceland.

Musa, Y., Nasaruddin, M.A., \& Kuruseng. (2007). Evaluasi produktivitas jagung melalui pengelolaan populasi tanaman, pengolahan tanah, dan dosis pemupukan. Agrisistem, 3(1), 21-33. 
0-fish. (2003). Parameter air. Online: http://www.0fish.com/parameter_air.htm. Diakses pada tanggal 22 Oktober 2011.

Patil, P.A., Dube, K., Verma, A.K., Chadha, N.K., Sundaray, J., \& Jayasankar, P. (2019). Growth performance of goldfish, Carassius auratus and basil, Ocimum basilicum in media bed aquaponics. Indian J. Fish., 66(1), 112-118.

Rakhman, F.M., Hasan, Z., Gumilar, I., \& Subhan, U. (2018). Efektivitas berbagai media tanam untuk mengurangi karbon organik total pada sistem akuaponik dengan tanaman selada. Jurnal Perikanan dan Kelautan UNPAD, IX(1), 35-48.

Ratannanda, R. (2015). Pemberian waktu tetensi sistem akuaponik untuk mereduksi limbah budidaya ikan nila (Oreochromis sp.). Skripsi. Departemen Budidaya Perairan Fakultas Perikanan dan IImu Kelautan. Institut Pertanian Bogor, Bogor.

Rakhman, F.M., Hasan, Z., Gumilar, I., \& Subhan, U. (2018). Efektivitas berbagai media tanam untuk mengurangi karbon organik total pada sistem akuaponik dengan tanaman selada. Jurnal Perikanan dan Kelautan UNPAD, IX(1), 35-48.

Ratannanda, R. (2015). Pemberian waktu tetensi sistem akuaponik untuk mereduksi limbah budidaya ikan nila
(Oreochromis sp.). Skripsi. Departemen Budidaya Perairan Fakultas Perikanan dan IImu Kelautan. Institut Pertanian Bogor, Bogor.

Ruly, R. (2011). Penentuan Waktu Retensi Sistem Akuaponik untuk Mereduksi Limbah Budidaya Ikan Nila Merah, Cyprinus sp. Skripsi. Departemen Budidaya Perairan Fakultas Perikanan dan IImu Kelautan Institut Pertanian Bogor, $25 \mathrm{hlm}$.

Tacon, A.G.J. (1987). The nutrition and feeding of farmed fish and shrimp. A Training Manual Food and Aquaculture Organization of United Nation Brazilia, Brazil.

Waynarovich, E. \& Horvarth, L. (1980). The artificial propagation of warm water fin fishes: A manual for extension. FAO Fisheries Technical Paper, 201, $183 \mathrm{pp}$.

Widyastuti, Y.R. (2008). Peningkatan produksi air tawar melalui budidaya ikan sistem akuaponik. Prosiding Seminar Nasional Limnologi IV LIPI. Bogor, 62-73.

Zailani \& Kadir. (1993). Estimasi penggunaan pupuk urea pada percobaan penanaman kangkung darat (Ipomoea reptans POIR) di Kecamatan Darussalam Kabupaten Aceh Besar. Laporan Penelitian. Universitas Syiah Kuala Darussalam Banda Aceh. 